\title{
Articles
}

\section{A cross-cultural study of value orientation and its effect on doctoral students' self-concept formation}

\author{
Danping Peng, Iva Koribská, Štefan Chudý
}

\begin{abstract}
Enormous changes in recent decades have led to the trend of higher education globalization. Globalization brings great opportunities for equity and quality in education to be realised for international students, however, it also poses challenges. Focused on doctoral students' self-concept formation, the current research adopted a qualitative approach to explore the value orientations of doctoral students and their self-concept formation, aiming to contribute to the literature on doctoral students' values and to the improvement of practice in higher education. Convenience sampling and random selection was used to select the participants. Four international doctoral students participated in this research. Based on the data collected, the researchers summarized the multifaceted self-concept formation, the role of value orientation in its formation and outlined the structure of the current support system.
\end{abstract}

Key words: value orientation, self-concept formation, cross-cultural adaptation, international doctoral students. 


\title{
Mezikulturní studie hodnotové orientace a jejího vlivu na formování sebepojetí doktorandů
}

\begin{abstract}
Abstrakt
Enormní změny v posledních desetiletích vedly $\mathrm{k}$ trendu globalizace vysokoškolského vzdělávání. Globalizace přináší značné příležitosti pro rovnost a kvalitu vzdělávání zahraničních studentů, ale zároveň představuje určité výzvy. Výzkum se zaměřil na formování sebepojetí doktorandů. K prozkoumání hodnotových orientací studentů doktorského studia a jejich sebepojetí bylo využito kvalitativního přístupu. Cílem výzkumu bylo přispět k odborné literatuře o hodnotách doktorandů a ke zlepšení praxe ve vysokoškolském vzdělávání. Výzkumný vzorek byl sestaven náhodným výběrem. Výzkumu se zúčastnili čtyři mezinárodní doktorandi. Na základě shromážděných údajů výzkumníci shrnuli mnohotvárné formování sebepojetí, úlohu hodnotové orientace při jejím formování a vytvořili strukturu stávajícího systému podpory.
\end{abstract}

Klíčová slova: hodnotová orientace, formování sebepojetí, mezikulturní adaptace, mezinárodní doktorandi.

DOI: 10.5507/epd.2019.011

\section{Introduction}

Enormous changes in the last few decades have led to the trend of higher education globalization. This new era of diversity in society has broadened the boundaries of higher education. Thus, the variables involved in higher education demand in-depth exploration. One of the essential components of higher education is the student. With the advocacy of education globalization, there is an increasing number of international students enrolled in universities. In the Czech Republic, even though it is not obligatory for universities to accept international students, the last decade has still witnessed an increasing number of international students admitted into universities (Czech statistical office, 2018).

Globalization brings with it great opportunities to achieve education equity and quality for international students, however it also poses challenges. Universities are confronted with various types of barriers that hinder the implementation of education, and there still many issues which remain in question. Do international students have access to the same educational resources as other students? Are international students merely physically included or are they socially included? Appropriate research and support should be tailored to meet the needs of every individual international student. 
A well-constructed system of research and support can greatly improve practices in higher education and can help all international students to reach their potential and success at universities.

According to the most recent information released by the Czech Statistics Office, the number of international doctoral students continues to increase. Compared to the number in 2003 (724), the numbers have increased to 2628 in 2017. International doctoral students as students and young researchers will, of course, have values of their own. Various issues and characteristics of doctoral students have been examined. Value orientation and self-concept formation are topics under increasingly heated debate. Focused on doctoral students' self-concept formation, the current research adopted a qualitative approach to explore the value orientations of doctoral students and their self-concept formation, aiming to contribute to the literature on doctoral students' values and to improve higher education practices.

Based on this topic, the research aims to answer the following questions related to the formation of doctoral students' self-concept in the Czech Republic:

What are the characteristics of doctoral students' value orientations in selected nationalities?

What are the functions of value orientation in the doctoral students' self-concept formation?

What support do the international doctoral students need?

What form do structures of the supporting systems constructed for international doctoral students in higher education take?

\section{Theoretical Framework}

This research is based mainly on three concepts and strands of literature: cross-cultural adaptation, value orientation and self-concept towards doctoral students in terms of self-concept formation.

\subsection{Cross-cultural adaptation}

The definition of cross-cultural adaptation is still under debate. There is no consensual definition of cross-culture adaptation or cultural adaptation. Some definitions focus on psychological adaptation (Ward, Bochner, \& Furnham, 2001); others focus on sociocultural adaptation (Bierwiaczonek \& Waldzus, 2016); whereas others may emphasize a dynamic process of cultural adaptation. For instance, the W-curve model (Gullahorn \& Gullahorn, 1963; Zeller \& Mosier, 1993) and the U-curve model (Lysgaard, 1955; Oberg, 1960). Put simply, researchers refer to the educational adaptation of international doctoral students within specific contexts. However, it does not merely mean physically 
including international students in higher education, the need for international students to participate into mainstream life are emphasised alongside being given access to the same learning opportunities and resources as other students; the research also emphasizes the universities' responsibility to provide support for students from diverse groups to meet students' development needs.

Brown and Holloway (2008) summarized some key characteristics of international students' cultural adaptation. They found that the most overwhelming period was at the beginning of the stay when negative symptoms caused by cultural differences were most noticeable.

In the current research, the researchers adopted the definition of "cross-cultural adaptation" from Lysgaard (1955). Cultural adaptation refers to the process and time a person needs to assimilate to a new culture, and included four different stages: the honeymoon stage, the culture shock stage, the recovery stage, and the adjustment stage.

\subsection{Value Orientation}

Value has been explored by different researchers and has different classifications. Schwartz (1992) divides values into two groups: individual and cultural. According to his value theory, values have six main features: "Values are beliefs; values refer to desirable goals; values transcend specific actions and situations; values serve as standards or criteria; values are ordered by importance; the relative importance of multiple values guides action" (Schwartz, 1992, p.4). Spranger (1928) investigated the classification of basic values, he divided them into six groups in his research: theoretical value; economical value; aesthetic value; social values; political value and religious value. Following those theories, the researchers assume that values function as an orientation principle and influence individual decision making, attitudes and behaviours by directing perception.

As for the term "value orientation", as one of the important features of being human, it has been analysed by more and more researchers. According to Ennis, Ross and Chen (1992), value orientations: "... are belief structures or philosophical positions that can be defined operationally in educational settings. They represent educational perspectives that influence the teachers' relative emphasis on the learner, the context and the body of knowledge. Value orientations are pervasive factors that determine the characteristics of a 'physically educated person' within alternative curricular perspectives" (p. 38).

In this research, the focus is placed on the international doctoral students' value orientations. In this respect, the areas of family, work and study, and social skills are analysed to enhance the understanding of their value orientation. 


\subsection{Self-concept formation}

Self-concept is considered a combination of various domains of the self and is viewed as an inclusive lifelong process (Sears, 1982). It is not an easy task to clarify the idea of "self-concept". It is even harder to describe the process of self-concept formation. For a better understanding of self-concept formation, Fitts and Warren (2003) proposed a multi-dimensional model of self-concept which includes six domains: physical (appearance, health, body), personal (attributes: honest, friendly, calm, forgiving, cheerful, and others), moral (good or bad values and acts), family (parents, family members), social (make friends, sociable) and academic (gifted/love Mathematics/intelligent).

Self-concept formation is a dynamic and changeable process; it can be developed. Franken (2007) found that self-concept can be reconstructed from negative to positive. Super (1963) and his colleagues emphasized the connection between career paths and perceptions of themselves, and a positive self-concept was highlighted. Besides this, Sharf (2012) noticed the external situational conditions of self-concept formation; the results showed that contextual interaction plays a vital role in the development of self-concept.

Based on the purpose of this research, the "self-concept formation" in this research is limited to those that connect to personal, family, social and academic. Therefore, in this research, the term "self-concept formation" of international doctoral students is defined as, "A developed process of individual's understanding of his or her totality of beliefs and thoughts, including personal connection with family, social and academic world in a new social context".

\section{Research methodology}

Qualitative research is "a form of inquiry that explores phenomena in their natural settings and uses multi-methods to interpret, understand, explain and bring meaning to them" (Anderson \& Arsenault, 2005, p. 126). This research adopted a qualitative paradigm to explore the international doctoral students' value orientation and self-concept formation.

The research was conducted in the Olomouc region of the Czech Republic. Palacky University in Olomouc is the oldest university in Moravia region and the second-oldest university in the Czech Republic. In 2017, 20395 students studied on accredited study programmes at eight faculties. 3,432 international students from 98 countries were accepted for study stays (Palacky University, 2017). Therefore, this university is considered as representative in this area. 


\subsection{Research Sample}

Convenience sampling and random selection was used to select the participants. The advantage of this approach is that the researchers can conduct the research and gain valuable, albeit limited, information about international doctoral students' value orientation. Four international doctoral students participated in this research. The following Table 1 shows the basic information of the participants:

Table 1

Basic information about participants

\begin{tabular}{|c|c|c|c|c|}
\hline Participants & Gender & Nationality & Age & Years in the Czech Republic \\
\hline Student 1 & Male & Chinese & 39 & 3 \\
\hline Student 2 & Male & Indonesian & 40 & 3 \\
\hline Student 3 & Female & Chinese & 29 & 4 \\
\hline Student 4 & Male & Chinese & 41 & 3 \\
\hline
\end{tabular}

\subsection{Instrument and Procedures}

Qualitative interviews, an important data collection method in qualitative research, refer to the process in which a researcher and participant engage in a conversation focused on questions related to the research study (DeMarrais, 2004). In this research, data was collected by semi-structured interviews with the participants. Four parts were included in the interviews: basic characteristics; questions focused on value orientation; questions focused on expectations and practice; and questions related to the university climate.

The interviews lasted from 40 to 70 minutes, but most of them were about one hour, which was the time stated in advance. The interviews were conducted in the English language.

\subsection{Data Analysis}

According to Corbin and Strauss (2015), analysis of data which happens throughout the research, is an art and a science, and involves interpretation. To maintain data accuracy in the current research, the data collected through interviews were transcribed immediately after the interview. All interview transcripts were sent to the participant for review and correction.

In accordance with procedures outlined by Corbin and Strauss (2015) the following coding procedures were implemented in the current research: open coding, axial coding, and selective coding. 


\section{Results}

With data analysis, the concepts that were developed in the open coding step have been grouped into categories and subcategories. Relations among those concepts, subcategories and categories were explored. With the ongoing process of data analysis, some important themes started to emerge.

\subsection{Multifaceted self-concept formation}

In the open coding step, multifaceted perceptions of self-concept formation were identified, varying from "fulfil inner desire", "enhance self-confidence", "self-development", "self-actualization", "harmonious coexistence". It shows the different understandings of the concept of "self-concept". The dynamic change of the understanding of self-concept is illustrated in Table 2.

Table 2

The dynamic change of the understanding of self-concept

\begin{tabular}{|l|l|l|}
\hline Childhood & Studying or working in domestic/home country & Studying in the Czech Republic \\
\hline Get out of hard living situation & Gain respected position & Self-actualization \\
\hline Fulfil parents' expectation & Fulfil curiosity, enrich self & Extend capabilities \\
\hline Contribution to family & Working harder is better & Challenge self and harmonious coexistence \\
\hline To upgrade knowledge & Looking for new experience & Self-development \\
\hline
\end{tabular}

As shown in Diagram 1, six main concepts (including family background, value orientation, relationship with supervisor, circle of friends and school climate, social culture) labelled in open coding step were found to have contributed to the change of self-concept in the axial coding process.

Family background: this includes parents' education level, location of the family, financial situation, marital status of the parents, and methods of communication. In general, family background is the initial impulse shaping self-concept. As the participants said:

S3: "They gave me motivation, this gives me a great value. My mother turned off the TV so that I could learn at night, I didn't have to worry about anything just prepare my homework, in the morning she prepared my breakfast."

S4: "My family lived in rural area, my parents were farmers. They hoped for their sons to learn more and to go to work in the city" 
Diagram 1

Factor influencing the changing of self-concept

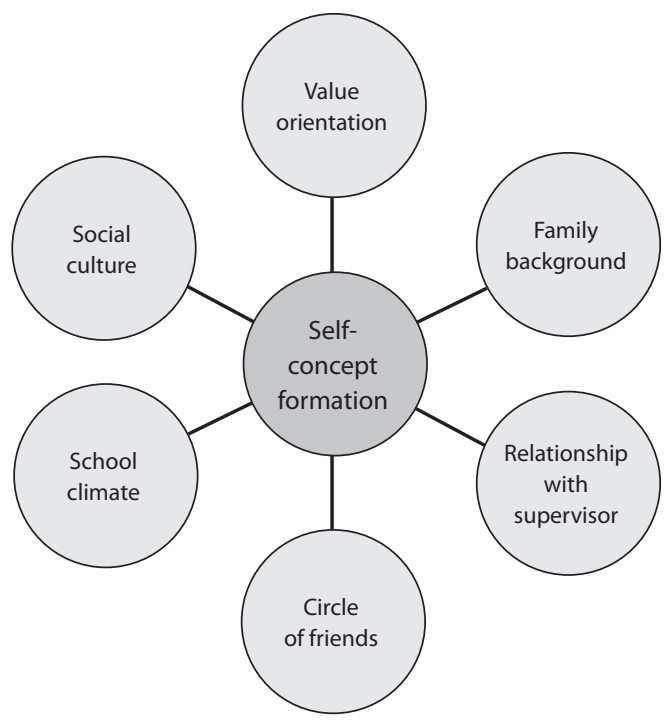

Relationships with supervisor: these differ from person to person, a positive and supportive relationship with the supervisor is crucial for international doctoral students to reach academic achievement. As the participants mentioned:

S1: "My supervisor is very good, like with my father, very detached. This is exactly what I need. Freedom, independence and support are very important"

S4: "I think my supervisor is like my mamma. First time I was so homesick that I cried in her office. She supported me."

S3: "My supervisor told me about the philosophy of education. It was something new for me. He is friendly and supportive"

The changing circle of friends was reported by participants as well. For instance:

S1: "But it is different, people are cold here. Just a few friends. My office is up in the corner only for me."

S2: "I have lots of friends here, very nice and friendly colleagues as well. But we are not so close, sometimes it's hard to understand each other." 
In this research, participants highlighted the importance of convenient online communication, which enabled them to talk with friends from home.

A comprehensive and open social culture, and a positive school climate are also important factors influencing the formation of self-concept. By interviewing the participants, the researchers at the target university found that the school climate is considered partly positive and comprehensive. As participant S1 said, "I think I'm partly supported, for example I got the project IGA, but there are no English books here that I can study".

\subsection{The role of value orientation}

By interviewing the participants, value orientation was found to be considered one of the most important factors influencing the participants' self-concept formation. Concepts including "views on society's values, views on family values, views on doctoral studies, views on the self-development, views on moral values" were developed during the open coding stage. These concepts were then categorized as "value orientation" in the axial coding step, as shown in Diagram 2.

\section{Diagram 2}

The role of value orientation

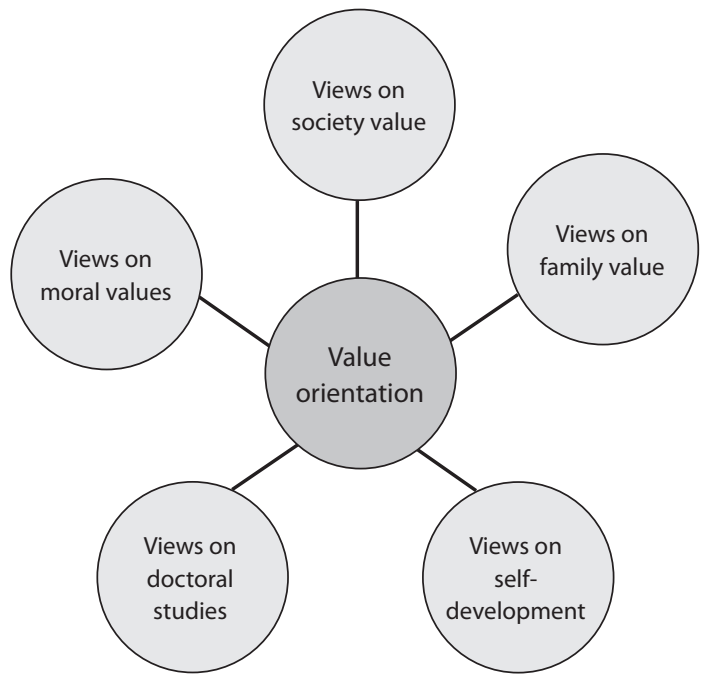


The value orientation of participants in this research varies from being autonomous or independent to being integrated or dependent. Data indicate that when the participants jumped from one society to another, their previous value orientations were altered by the changing circumstances which shaped the formation of self-concept. The participants who were autonomous tended to have a more positive self-concept in the new environment. As participant S1 said, "Freedom, independence and support are very important... For doctoral students it is very important to depend on yourself." However, it does not mean participants who were less independent will not have a positive selfconcept in the new place. They are more sensitive about the changing environment, so their self-concept formation takes more time to develop. For instance, S2 said, "my parents, and other family members and my friends... we are really close; being here, I don't have so many close friends but I fully understand this culture and I like the way people live here, I have no problem, it just takes time to be ' $m e^{\prime \prime}$.

\subsection{Structure of the supporting systems}

Better formation of positive self-concept in international doctoral students, requires appropriate supports. In the open coding phase, by scrutinizing the interview transcripts, various required supports were identified, such as: "improving academic writing", "language training", "prompts for interaction", "prompt feedback" and so on. In the axial coding phase, the five categories of support were all placed under the category "support needed by international doctoral students in positive self-concept formation" as illustrated in table 3 .

Table 3

Supports needed by international doctoral students in positive self-concept formation

\begin{tabular}{|l|l|}
\hline Peer interaction & $\begin{array}{l}\text { Friendships } \\
\text { Relationship with colleagues } \\
\text { Prompts for interaction }\end{array}$ \\
\hline Teacher support & $\begin{array}{l}\text { Prompt feedback } \\
\text { Professional guidance and cooperation } \\
\text { Harmonious relationships } \\
\text { Substantial study resources } \\
\text { Psychological counselling }\end{array}$ \\
\hline Financial support & $\begin{array}{l}\text { Scholarships } \\
\text { Project funding }\end{array}$ \\
\hline Professional training & $\begin{array}{l}\text { Language training (English and (zech) } \\
\text { Improving academic writing }\end{array}$ \\
\hline Family support & $\begin{array}{l}\text { Love and belonging } \\
\text { Stable and harmonious family relationships }\end{array}$ \\
\hline
\end{tabular}


With regards to the structure of the support system, emphases have been placed on the internal structure of the university and on the roles played by different support providers. Diagram 4 shows the structure of the support system for international doctoral students. The socio-ecosystem of the international doctoral students consisted of the classroom, the office, department, dormitory, library and the society. These different components were involved in this process to different extents.

People involved in the system provided direct or indirect support for the students. Support providers included teachers, supervisors, administrative staff, directors, library staff, other professionals, and sometimes colleagues and friends etc.

\section{Diagram 3}

Structure of the supporting system

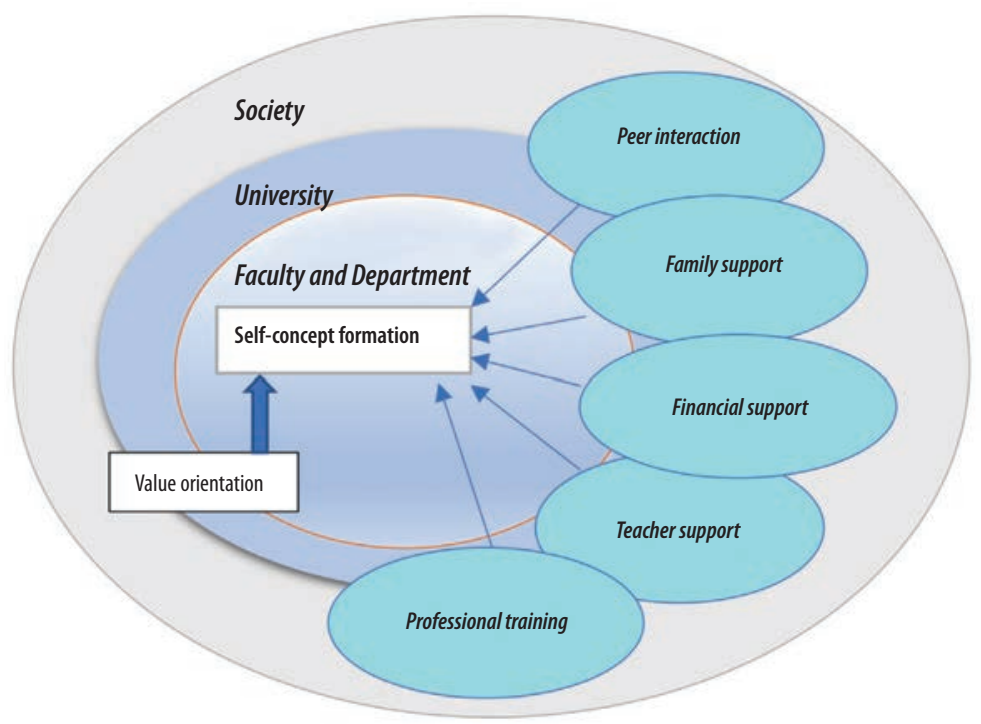




\section{Conclusion}

As described in the first part of this research, international doctoral students have various difficulties in their new environment and face some barriers in adapting to their new study life. Based on the data collected, the researchers summarized the multifaceted self-concept formation, discussed the role of value orientation in participants' self-concept formation and outlined the structure of the current supporting system. Higher education should consider students' needs, learning styles, contextual differences etc. For the international doctoral students' self-concept formation, a well-structured support system should underpin the efforts of individuals and organizations providing continuous services to international doctoral students and should provide stable support that can meet the varying needs of international doctoral students therefore, to ensure positive self-concept formation.

The inadequate functioning of the current support systems is closely related to the problems existing in the systems. First, the connection of internal structures of the support systems were weak. In most cases, teacher support was only related with professional training, and sometimes connected to financial support. Family support or peer interaction was not actively involved in school-based study. Secondly, the collaboration between different support providers was insufficient. The service providers should collaborate with each other to help the adaptation of international students. Teamwork should be emphasized amongst different parties. However, due to weak internal structures, collaboration between providers was also insufficient.

\section{Acknowledgment}

This research has been financially supported by the Palacký University Olomouc (by the grant of IGA_PDF_2018_016 and IGA_PDF_2018_019).

\section{References}

Anderson, G., \& Arsenault, N. (2005). Fundamentals of educational research ( $2^{\text {nd }}$ ed.). Philadelphia, PA: Taylor \& Francis e-Library.

Bierwiaczonek, K., \&Waldzus, S. (2016). Socio-cultural factors as antecedents of cross-cultural adaptation in expatriates, international students, and migrants: A review. Journal of Cross-Cultural Psychology, 47(6), 767-817. https://doi.org/10.1177/0022022116644526.

Brown, L. \& Holloway, I. (2008). The initial stage of the international sojourn: Excitement or culture shock? British Journal of Guidance \& Counseling, 36(1), 33-49.

Corbin, J., \& Strauss, A. (2015). Basics of qualitative research: Techniques and procedures for developing grounded theory. Thousand Oaks, Cal: Sage. 
Czech statistical office. (2018). Data on education of foreigners, Retrieved from https://www.czso. cz/documents/11292/32508273/c04R47_2017.pdf/a121e19d-6e33-4197-9af1-04656be4ebb3? version $=1.0$.

DeMarrais, K. B. (2004). Qualitative interview studies: Learning through experience. In DeMarrais, K. B., \& Lapan, S. D. (2004). Foundations for research: Methods of inquiry in education and the social sciences. Mahwah: Lawrence Erlbaum Associates.

Erdem-Keklik, D. (2016). Value orientations of candidate teachers in knowledge society. Eurasian Journal of Educational Research, 66, 355-372. DOI: 10.14689/ejer.2016.66.20. Retrieved from: http://ejer.com.tr/public/assets/catalogs/en/devrimerdem66.pdf.

Ennis, C. D., Chen, A., \& Ross, J. (1992). Educational value orientations as a theoretical framework for experienced urban teachers' curricular decision. Journal of Research and Development in Education, 25(3) pp. 156-163.

Fitts, W. H., \& Warren, W. L. (2003). Tennessee Self Concept Scale TSCS: 2 (2 ${ }^{\text {nd }}$ ed.). Los Angeles, CA: WPS.

Fitts, W. H., \& Warren, W. L. (2003). Tennessee self-concept scale: TSCS-2. Los Angeles, California: Western Psychological Services.

Gullahorn, J. T., \& Gullahorn, J. E. (1963). An extension of the U-curve hypothesis. Journal of Social Issues, 19(3), 33-47. Retrieved from http://dx.doi.org/10.1111/j.1540-4560.1963.tb00447.x.

Lysgaard, S. (1955). Adjustment in a foreign society: Norwegian Fulbright grantees visiting the United States. International Social Science Bulletin, 7(1), 45-51.

Oberg, K. (1960). Cultural shock: Adjustment to new cultural environments. Practical Anthropology, 7(4), 177-182. Retrieved from https://doi.org/10.1177/009182966000700405.

Palacky University. (2017). Statistical Data. Retrieved from https://www.upol.cz/en/university/ basic-information/.

Schwartz, S. H. (1992). Universals in the Content and Structure of Values: Theoretical Advances and Empirical Tests in 20 Countries. In Zanna, M. (Ed.). Advances in Experimental Social Psychology, 25,1-65. New York: Academic Press. Retrieved from https://doi.org/10.1016/S00652601(08)60281-6.

Spranger, E. (1928). Types of men. The psychology and ethics of personality. Oxford, England: Niemeyer.

Sears, S. (1982). A definition of career guidance terms: A National Vocational Guidance Association perspective. The Career Development Quarterly, 31(2), pp. 137-143. Retrieved from http:// dx.doi.org/10.1002/j.2164-585X.1982.tb01305.x.

Super, D. E. (1963). Self-Concepts in Vocational Development. In D. E. Super, R. Starishevsky, N. Matlin, \& J. P. Jordaan (Eds.). Career Development: Self-concept Theory. New Jersey: College Entrance Examination.

Ward, C. A., Bochner, S. \& Furnham, A. (2001). The psychology of culture shock. Hove, England: Routledge.

Zeller, W. J., \& Mosier, R. (1993). Culture shock and the first-year experience. Journal of College and University Student Housing, 23 (2).

\section{Contacts:}

Danping Peng, Ph.D.

Mgr. Iva Koribská

doc. Mgr. Štefan Chudý, Ph.D.

Institute of Education and Social Studies

Faculty of Education, Palacký University

Žižkovo nám. 5, 77140 Olomouc, Czech Republic

E-mails: danping.peng@upol.cz, iva.koribska@upol.cz, stefan.chudy@upol.cz 
Danping Peng, Ph.D., assistant professor works as University Lecturer at the Institute of Education and Social Studies, Palacky University in Olomouc. She holds a PhD in Education. Her research interests include professional development of headteachers, school management and pedagogical leadership in schools providing compulsory education.

doc. Mgr. Štefan Chudý, Ph.D., head of the Institute of Education and Social Studies, Faculty of Education of the Palacký University in Olomouc guarantees subjects such as theory of educations, philosophy of education and social pedagogy. He is oriented on research into the development of the key competencies of social pedagogues, the preparation of students (i.e. future teachers) and on the resolution of remedial behavioral situations. The field of his scientific research is decision competences, school discipline.

Mgr. Iva Koribská is a doctoral student of study programme Education at the Institute of Social Sciences and Education, Palacký University, Olomouc, where she also works as an assistant. She specializes on Adult Education and the factors building the professional self-concept of academic workers. 